\title{
Antimicrobial, Cytotoxic and Phytotoxic Potency of Ethyl Acetate Extract of Rhizopus stolonifer Culture
}

\author{
Mudassar lqbal $^{1 *}$, Muhammad Amin ${ }^{1}$, Zafar lqbal ${ }^{1}$, Hamida Bibi ${ }^{2}$, Amjad lqbal $^{3}$, \\ Zia-ud Din ${ }^{4}$, Muhammad Suleman ${ }^{1}$ and Hamid Ullah Shah ${ }^{1}$ \\ ${ }^{1}$ Department of Agricultural Chemistry, ${ }^{2}$ Department of Soil and Environmental Sciences, The University of Agriculture, \\ Peshawar, Pakistan, ${ }^{3}$ Science and Advice for Scottish Agriculture, Edinburgh, EH12 9FJ, United Kingdom, Department of \\ Human Nutrition, The University of Agriculture Peshawar
}

*For correspondence: Email: mudassariqbal@aup.edu.pk; Tel: +92 346 9211142; Fax: +92919216520

Received: 14 January 2013

Revised accepted: 7 November 2013

\begin{abstract}
Purpose: To evaluate the antimicrobial, cytotoxic and phytotoxic activities of the organic extract of Rhizopus stolonifer whole cell static culture in order to determine the presence of potentially bioactive compounds in the culture.

Methods: The organic extract was obtained by extracting the whole cell culture of $R$. stolonifer with Ethyl Acetate (EtOAc). The antifungal activity was determined by inhibitory effect on the growth of Alternaria alternate, Aspergillus flavus, Curvularia protuberata and Fusarium oxysporum, cytotoxic activity by brine shrimp lethality test, antibacterial activity against Ervinia carotovora and Xanthomonas campestris by disc diffusion technique, and phytotoxic activity by testing the crude extract against the Lemna minor frond.

Results: The extract showed phytotoxic activity (at 95\% level of significance) against Lemna minor $\left(67.7 \%\right.$ lethality) with Fronds Inhibition ( $\left.\mathrm{FI}_{50}\right)$ of $167.85 \mu \mathrm{g} \mathrm{mL} \mathrm{L}^{-1}$. The extract exhibited a significant (at $95 \%$ level of significance) cytotoxic activity ( $L C_{50}$ of $115.71 \mu \mathrm{g} \mathrm{mL}^{-1}$ ) against brine shrimp. Maximum mortality (56.7\%) was obtained at a concentration of $200 \mu \mathrm{g} \mathrm{mL} \mathrm{L}^{-1}$ concentration after $48 \mathrm{~h}$. In the antifungal test, the highest inhibitory effect was observed against Fusarium oxysporum (88.8\%) followed by Alternaria alternata (81.5\%), Aspergillus flavus (70.5\%) and Curvularia protuberata (37.5 $\%)$ at $1000 \mu \mathrm{g} . \mathrm{mL}^{-1}$ when compared to negative reference. Antibacterial activity against Ervinia carotovora and Xanthomonas campestris was minimal even at extract level of $2000 \mu \mathrm{g} \mathrm{mL}^{-1}$.

Conclusion: The ethyl acetate extract of $R$. stolonifer possesses significant herbicidal, cytotoxic and antifungal properties. Isolation and characterization is required for structural elucidation of its bioactive compounds.
\end{abstract}

Keywords: Rhizopus stolonifer, Antifungal, Antibacterial, Phytotoxicity, Cytotoxicity.

Tropical Journal of Pharmaceutical Research is indexed by Science Citation Index (SciSearch), Scopus, International Pharmaceutical Abstract, Chemical Abstracts, Embase, Index Copernicus, EBSCO, African Index Medicus, JournalSeek, Journal Citation Reports/Science Edition, Directory of Open Access Journals (DOAJ), African Journal Online, Bioline International, Open-J-Gate and Pharmacy Abstracts

\section{INTRODUCTION}

Various species in nature are capable of producing diverse class of natural compounds in the form of secondary metabolites. Indeed, some of the metabolites possess useful biochemical activities such as phytotoxicity, cytotoxicity, nematocidal and antimicrobial properties. In the last few decades, it has been observed that fungi are excellent source of potent bioactive secondary metabolites. The secondary metabolites from fugal strains play a vital role in health and maintenance of ecosystems [1]. Some of the fungal metabolites such as mycotoxins have the ability to cause diseases and are potentially harmful to livestock and human [2]. On the other hand, however, fungi and fungal metabolites can be used in a 
beneficial manner, for example, medicinal uses, fermentation processes, phytotoxic activity against weeds and antimicrobial applications [3]. It has been estimated that over $40 \%$ of medicines used today have their origin in natural products among which are fungal metabolites [4]. Fungal metabolites have been extensively investigated worldwide in the last few decades but less work has been documented on fungal flora and their metabolites in Pakistan. Our aim is to isolate bioactive compounds from native fungal species of Pakistan to screen them for bioactivities as prospective candidates for potential pharmaceutical or agrochemical applications. The present study is, therefore, designed to screen the ethyl acetate extract of the whole cell culture of Rhizopus stolonifer for bioassays including antimicrobial, phytotoxic and cytotoxic activities.

\section{EXPERIMENTAL}

\section{Materials}

Fungi (Rhizopus stolonifer), Potato Dextrose Agar (PDA), Laminar flow Unit, Ethyl acetate (EtOAc), Dimethyl Sulfoxide (DMSO), Methanol, Whatman filter paper, E-Medium (aqueous medium where the natural growth of lamena minor occurs), rotary evaporator

\section{Methodology}

The culture of $R$. Stolonifer was obtained from the Department of Plant Pathology, University of Agriculture, Peshawar, Pakistan. The isolates were repeatedly sub-cultured on potato dextrose agar plates to obtain pure isolates of $R$. Stolonifer. A slant from the mature culture of $R$. stolonifer over agar was inoculated in $500 \mathrm{~mL}$ potato dextrose broth in $1000 \mathrm{~mL}$ conical flask and incubated at room temperature $\left(30 \pm 2{ }^{\circ} \mathrm{C}\right)$ for 12 days. The whole cell culture was homogenized using a blender and extracted with $500 \mathrm{~mL}$ EtOAc. The cells were separated by filtration under vaccum, the organic fraction dried over anhydrous $\mathrm{MgSO}_{4}$ and evaporated in vacuo. The crude extract was obtained as a brown viscous oil (3.2 g) and was employed in the bioassays.

\section{Determination of antifungal activity}

The fungicidal activity of $R$. stolonifer extract was measured against some pathogenic fungi using growth rate method. [5]. The crude EtOAc extract was dissolved in DMSO to make a stock solution with a concentration of $1000 \mathrm{Mg} \mathrm{mL}^{-1}$; this was further diluted to $500 \mathrm{\mu g} \mathrm{mL}^{-1}$ and $250 \mathrm{\mu g} \mathrm{mL}^{-1}$. These solutions were dissolved in PDA media and poured onto petri dishes. The fungi, Alternaria alternate, Aspergillus flavus, Curvularia protuberata and Fusarium oxysporum were used as test pathogens. An agar plug from each mature culture, of $5 \mathrm{~mm}$ in diameter, was obtained using a sterilized cork borer and placed in the center of each agar plate. Blank and a fungicide (positive control, Diethane M45, $100 \mu \mathrm{g}$ $\mathrm{mL}^{-1}$ ) were also run in parallel. The Petri dishes, in triplicate, were incubated at room temperature for 7 days and the growth of the fungal strains observed regularly. The zone of mycelial growth was measured (in $\mathrm{mm}$ ) using a transparent scale. Inhibitory activity was calculated from Eq 1.

$$
\mathrm{IE}(\%)=\{(\mathrm{DC}-\mathrm{DS}) /(\mathrm{DC}-5)\} \times 100
$$

where IE = inhibitory effect, $\mathrm{DC}=$ diameter of negative control $(\mathrm{mm}), \mathrm{SD}=$ diameter of sample (mm), 5 mmof agar plug used

\section{Evaluation of antibacterial activity}

Disk diffusion method was performed for screening for antibacterial activity. Different concentrations of the crude extract of $R$. stolnifer (1000, 500 and $250 \mu \mathrm{g} \mathrm{mL}^{-1}$ ) were prepared in DMSO and loaded on sterile whatman filter paper disk (5 $\mathrm{mm}$ diameter). Two strains of bacteria, i.e., Erwinia carotovora and Xanthomonas campestris were used as target strains of bacteria. The bacteria were inoculated by streaking on PDA and the filter paper disk was loaded with the extract, it was dried in LFU and was placed on the bacterial colonies. The petri dishes were incubated at $30{ }^{\circ} \mathrm{C}$ for $48 \mathrm{~h}$. Streptomycin $\left(100 \mu \mathrm{g} \mathrm{mL}^{-1}\right)$ was used as a positive control. The experiment was carried out in triplicate and the zones of inhibition are shown as mean with standard errors.

\section{Determination of phytotoxic activity}

Phytotoxicity can be indicative of herbicidal activity and it was performed by measuring the lethality of the extract against Lemna minor plant [6] The extract $(10 \mathrm{mg})$ was dissolved in $2 \mathrm{~mL}$ methanol $(\mathrm{MeOH})$ to make a stock solution. Different concentrations of the extract ranging from $10-200 \mu \mathrm{g} \mathrm{mL}^{-1}$ were prepared from the stock solution, each transferred to a glass and the solvent allowed to evaporate overnight. The sterilized E-medium (100 $\mathrm{mL}$ ) was poured on the glass containing dried extract and 10 rosettes of Lemna minor, each containing three fronts, were placed on it. A negative control as well as a positive control (atrazine) was run in parallel under constant supply of tungsten light at room temperature for 7 days. The growth of Lemna minor was determined by counting the number of 
effected fronts (appearance of yellow color). The phytotoxicity was calculated by comparison with negative control. The $\mathrm{FI}_{50}$ (50 \% frond inhibition) value was calculated from probit analysis.

\section{Assessment of brine shrimp lethality test (BSLT)}

This bioassay is a simple and effective method for prescreening of bioactive compounds for cytoxicity and antitumor activity [7]. The brine shrimps lethality of the extract was performed by the procedure described of Oley and coworkers [8]. The nauplii were hatched in brine (35\% aqueous sea salt solution). The one-day hatched napulli were then added (30 in number) to vials containing different concentrations of the extract $\left(10,50,100\right.$ and $\left.200 \mu \mathrm{g} \mathrm{mL}^{-1}\right)$ in $15 \mathrm{~mL}$ brine with $1 \%$ DMSO. DMSO was used to increase the solubility of the extract in brine. Three replicates were used for each concentration; blank (15 mL brine with $1 \%$ DMSO) was also run as negative control. The toxicity of each sample was compared with that of blank (brine solution with out crude extract) and $\mathrm{LC}_{50}$ (lethal concentration that kills $50 \%$ population) was calculated by probit analysis.

\section{Statistical analysis}

All the experiments were executed in triplicate and the data is presented as mean \pm SEM in the results. The data were analyzed by ANOVA followed by LSD at $5 \%$ level of significance using SPSS 16, (IBM, Chichago, IL). LC 50 and $\mathrm{Fl}_{50}$ were calculated using probit analysis (95\% confidence interval) regression equations and $\mathrm{X}^{2}$ value (df).

\section{RESULTS}

\section{Antimicrobial activity}

All the extract concentrations showed inhibitory activity against mycelia growth of test fungal pathogens as shown in Table 1. Fusarium oxysporum (88.8\%) followed by Alternaria alternata (81.5\%), Aspergillus flavus (70.5\%) and Curvularia protuberata $(37.5 \%)$ at $1000 \mu \mathrm{g}$. $\mathrm{mL}^{-1}$ when compared to negative reference, diethance M45 as a positive control inhibited $100 \%$ of the fungal colonies.

The results of the antibacterial test are presented in Table 2, and they show the extract's weak antibacterial activity against the test bacteria, even at $1000 \mathrm{mg} \mathrm{mL}^{-1}$, compared with both the positive control (streptomycin).

Table 2: In-vitro antibacterial activity (mean \pm SEM, $n$ $=3$ ) of $R$. stolonifer extract $\left(1000 \mu \mathrm{g} \mathrm{mL}^{-1}\right)$

\begin{tabular}{|c|c|c|}
\hline \multirow[b]{2}{*}{ Sample } & \multicolumn{2}{|c|}{ Zone of inhibition (diameter, mm) } \\
\hline & $\begin{array}{c}\text { Erwinia } \\
\text { spp }\end{array}$ & Xanthomonas \\
\hline Extract* $^{*}$ & $2.30 \pm 0.58$ & $1.00 \pm 1.00$ \\
\hline $\begin{array}{l}\text { Positive } \\
\text { control }^{* *}\end{array}$ & $80.00 \pm 0.00$ & $80.00 \pm 0.00$ \\
\hline $\begin{array}{l}\text { Negative } \\
\text { control }^{* * *}\end{array}$ & 0.00 & 0.00 \\
\hline
\end{tabular}

\section{Phytotoxic activity}

Atrazine (positive control) exhibited $98.7 \%$ mortality against Lemna minor while the extract (200 $\mu \mathrm{g} \mathrm{mL} \mathrm{mL}^{-1}$ ) showed $67.7 \%$ mortality after seven days, compared to negative control (2.3 \%) . mortality. $\mathrm{FI}_{50}$ value was $168 \mu \mathrm{g} \mathrm{mL}^{-1}$.

\section{Brine shrimp Lethality Test (BSLT)}

After $24 \mathrm{~h}$, the highest shrimp mortality (41.0\%) was recorded at extract concentration of $200 \mu \mathrm{g}$ $\mathrm{mL}^{-1}$ concentration while only $14.3 \%$ mortality was observed at $10 \mu \mathrm{g} \mathrm{mL}^{-1}$ concentration (Fig 2). $\mathrm{LC}_{50}$ value was $388.60 \mu \mathrm{g} \mathrm{mL} \mathrm{g}^{-1}$ after $24 \mathrm{~h}$ but decreased to $115.70 \mu \mathrm{g} \mathrm{mL}-1$ after $48 \mathrm{~h}$ with lethality also increasing to $56.7 \%$ at extract concentration of $200 \mu \mathrm{g} \mathrm{mL} \mathrm{mL}^{-1}$; only $4.3 \%$ mortality was observed for blank (negative control).

Table 1: Antifungal activity of the EtOAc whole cell extract of $R$. stolonifer against selected fungal isolates

\begin{tabular}{|c|c|c|c|c|c|}
\hline \multirow{3}{*}{$\begin{array}{l}\text { Fungal } \\
\text { isolate }\end{array}$} & \multirow{3}{*}{$\begin{array}{l}\text { Positve control } \\
\text { (diethane M45) }\end{array}$} & \multicolumn{4}{|c|}{ Zone of growth \pm SEM (mm) } \\
\hline & & \multicolumn{3}{|c|}{ Extract concentrations $\left(\mu g \cdot \mathrm{mL}^{-1}\right)$} & \multirow{2}{*}{$\begin{array}{l}\text { Negative } \\
\text { control }\end{array}$} \\
\hline & & 1000 & 500 & 250 & \\
\hline A. flavus & $0.00(100 \%)$ & $23.7 \pm 1.3(70.5)$ & $35.3 \pm 1.4(52.1)$ & $53.0 \pm 1.7(24.2)$ & $68.3 \pm 0.5$ \\
\hline A. alternata & $0.00(100 \%)$ & $16.7 \pm 2.6(84.5)$ & $34.0 \pm 2.1(61.5)$ & $46.0 \pm 3.1(45.6)$ & $80.3 \pm 0.2$ \\
\hline F. oxysporum & $0.00(100 \%)$ & $13.3 \pm 1.4(88.8)$ & $21.0 \pm 2.1(78.5)$ & $36.3 \pm 1.8(57.8)$ & $79.3 \pm 0.2$ \\
\hline C. protuberata & $0.00(100 \%)$ & $57.6 \pm 3.3(37.5)$ & $70.3 \pm 2.0(22.5)$ & $80.7 \pm 1.7(10.2)$ & $89.3 \pm 0.4$ \\
\hline
\end{tabular}


The results of the antibacterial test are presented in Table 2, and they show the extract's weak antibacterial activity against the test bacteria, even at $1000 \mathrm{mg} \mathrm{mL}^{-1}$, compared with both the positive control (streptomycin).

Table 2: In-vitro antibacterial activity (mean \pm SEM, $n$ $=3$ ) of $R$. stolonifer extract $\left(1000 \mu \mathrm{g} \mathrm{mL}^{-1}\right)$

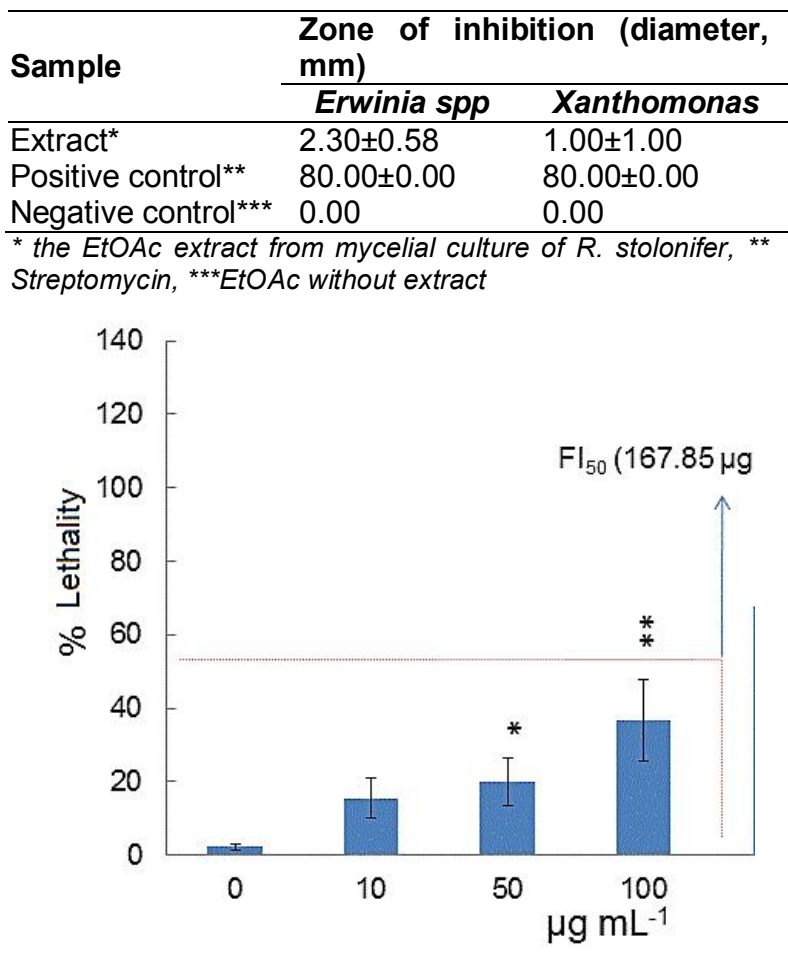

Figure 1: Effect of $R$. stolonifer extract on mortality (mean \pm SEM) of Lemna minor fronds. Atrazine was used as +ve control, while E-medium was used as -ve control. * $p<0.05 ;{ }^{* *} p<0.001$; ${ }^{* *} p<0.0001$, compared with appropriate control are indicated;

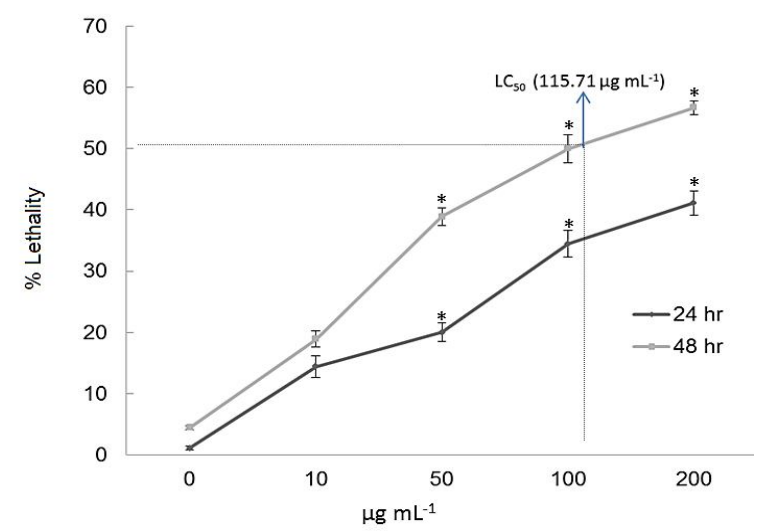

Figure 2: Brine shrimp lethality (mean \pm SEM, $n=3$ ) of $R$. stolonifer extract after 24 and $48 \mathrm{~h}$; Brine $(0 \mu \mathrm{g}$ $\mathrm{mL}^{-1}$ ) served as control; * $p<0.001$ compared with control

\section{DISCUSSION}

The ethyl acetate extract of the cell culture of $R$. stolonifer exhibited significant antifungal activity thus indicating that it can be utilized for the development of antifungal drug candidates. Some fungi are well known for the production of antifungal compounds including a group of strobilurins extracted from Strobilurus tenacellus $[9,10]$. Similarly, a fungus, Trichoderma herzianum is well known for its biocontrol activity against various fungi [11]. The organic extract possessed a potent inhibition activity (88.8\%) against Fusarium oxysporum, a plant pathogen that is hazardous to humans [12]. Similarly, the present work found that $R$. stolonifer cell culture extract showed $84.5 \%$ inhibition of Alternaria alternata, a highly pathogenic fungi of plants that cause leaf spots, rots and blights, and in humans, they causes asthma and upper respiratory tract infections [13]. Aspergillus flavus is a known producer of aflatoxins which are carcinogenic compounds and also cause aspergillosis [14]. The extract of $R$. stolonifer inhibited the growth of this pathogenic fungus by $70.5 \%$. The results of the present study suggest $R$. stolonifer extract contains metabolites that can be useful for fungicide development but lack antibacterial properties. Past researches demonstrated that the antifungal properties of plant extracts have varying degree of growth inhibitory effects against some filamentous fungi and yeast [15]. Furthermore the cell wall of fungi may be considered to be a prime target for selective toxicity because of its chitineous structure. Shukla et al [16] have shown that ether and ethyl acetate seed extracts of $C$. bonducella had antifungal activity against $A$. niger which might be due to the presence of steroids and saponin. Also the use of saponins from Tribulus terrestris exert antifungal activity by inhibiting fungal hyphae and destroying the ultra structure of fungi in particular [17], our results are in strong agreement with their findings.

Phytotoxicity of $R$. stolonifer extract was carried out against Lemna minor, a commonly used plant to assess the allelopathic effect of chemicals on its growth [18]. The $\mathrm{FI}_{50}$ value $\left(167.85 \mu \mathrm{g} \mathrm{mL}{ }^{-1}\right)$ indicates that the extract may contain herbecidal compounds; however, further studies to isolate the bioactive compounds are required to characterize and identify the active compound(s) responsible for the extract's herbicidal potential. In general allelopathic compounds affects physiological process including photosynthesis, chlorophyll production, plant-water relation, respiration, seed germination etc. phenolic compounds however affects net photosynthetic 
rate and stomatal conductance of single, fully expended leaves in receiver plants [19]

Brine shrimps larve (Artemia salina L.) are known for their use as a test organism to determine the cytotoxic potential of antifungal agents [20]. It has also been reported that brine shrimp lethality shows a positive correlation with cytotoxicity against 9KB human nasopharyngel carcinoma and human solid tumour cell lines [6]. LC LC $_{50}$ values $<250 \mathrm{\mu g} \mathrm{mL}^{-1}$ is indicative of cytotoxicity [21]. Thus, $\mathrm{LC}_{50}$ value of $115.71 \mu \mathrm{g} \mathrm{mL}-1$ for $R$. stolonifer extract indicates its potent cytotoxicity. This suggests that the extract may contain some metabolites that exhibit anticancer activity. Similarly, W. somnifera has been reported in treatment of cancer and various other diseases [22]. In past research on animal cell cultures it has been observed that this herb performs various functions in body (i.e. decreases the levels of the nuclear factor kappaB, suppresses the intercellular tumor necrosis factor, and potentiates apoptotic signaling in cancerous cell lines) [23]. Davis and Kuttan, [24] has shown that $W$. somnifera have stimulatory effects, both in vitro and in vivo, on the generation of cytotoxic $\mathrm{T}$ lymphocytes, and a demonstrated potential to reduce tumor growth.

\section{CONCLUSION}

The ethyl acetate extract of $R$. stolonifer has potent cytotoxic activity against brine shrimps, suggesting that it could serve as a lead compound for anticancer compounds. Its antifungal activity also indicates its potential for development into an antifungal product. Furthermore, its phytotoxicity against Lemna minor weed demonstrates that it contains compounds with herbicidal activity. Further studies, including isolation and structural characterization of its constituents could lead to the development of pharmaceutical and agricultural products.

\section{ACKNOWLEDGMENT}

The authors thank Higher Education Commission Pakistan and Directorate of Science and Technology for financial assistance. Thanks also to Prof Saifullah, Chairman, Plant Pathology Department, University of Agriculture, Peshawar, Pakistan for the use of his departmental facilities.

\section{REFERENCES}

1. Carroll, George C,; Wicklow, Donald T, . The Fungal community: Its organization and Role in the ecosystem. Vol 6. New York: CRC Press; 1992; pp 17-27.
2. Dalldorf G. Fungi and Fungal Disease. Illionis, US: Thomas Publishers, Springfield; 1962; pp 178.

3. Ainsworth, Geoffery C.; Sussman, Alfred S, editiors. The Fungi III: the fungal population. New York: Academic Press; 1968; pp 668.

4. Butler MS. The role of natural product chemistry in drug discovery. J. Nat. Prod., 2004; 67: 2141-2153.

5. Yin G, Wang W, Sha S, Liu LXY. Inhibition and control effects of the ethyl acetate extract of Trichoderma harzianum fermented broth against Botrytis cinerea. Afric. J. Microbiol. Res, 2010; 4: 16471653.

6. Mclaughlin JL, Rogers LL, Anderson JE. The use of biological assays to evaluate botanicals. Drug Inf. J. 1998; 32: 513-524.

7. Meyer, BN, Ferrigni NR, Putnam JE, Jacobsen LB, Nichols DE, Mclaughlin JL. Brine Shrimp, a Convenient General Bioassay for Active-Plant Constituents. Planta Med., 1982; 45: 31-34.

8. Oly WT, Islam W, Hasan P, Parween S. Antimicrobial activity of Clerodendrum ciscocum vent. (Verbenaceae). Int. J. Agric. Biol. 2011; 13: 222226.

9. Anke T, Oberwinkler F, Steglich W, Schramm G. The strobilurins new antifungal antibiotics from the basidiomycete Strobilurus tenacellus. J. Antibiot., 1977; 30, 806.

10. Balba $H$. Review of strobilurin fungicide chemicals. J. Envir. Sci. \& Health Part B, 2007; 42: 441-451.

11. Elad $Y$, Chet I, Katan J. Trichoderma harzianum: $A$ biocontrol agent effective against Sclerotium rolfsii and Rhizoctonia solani. Phytopathol. 1980; 70: 119-121.

12. Nelson PE, Dignani MC, Anaissie EJ. Taxonomy, biology and clinical aspects of Fusarium species. Clin. Microbiol. Rev., 1994; 7: 479-504.

13. Wiest PM, Wiese $K$, Jacobs MR, Morrissey AB, Abelson TI, Witt W, Lederman MM. Alternaria infection in a patient with acquired immunodeficiency syndrome: case report and review of invasive alternaria infections. Rev. Infect. Dise., 1987; 9: 799-803.

14. Diener UL, Cole RJ, Sanders T, Payne GA, Lee LS, Klich MA. Epidemiology of Aflatoxin Formation by Aspergillus Flavus. Ann. Rev. Phytopathol., 1987; 25: 249-270.

15. Irkin R, Korukluoglu M. Control of Some Filamentous Fungi and Yeasts by Dehydrated Allium Extracts. J. Verbr. Lebensm, 2009; 4(1): 3-6.

16. Shukla S, Mehta P, Mehta A, Vyas SP, Bajpai VK. Preliminary phytochemical and antifungal screening of various organic extracts of caesalpinia bonducella seeds. Roman. Biotechnolog. Lett., 2011; 16(4): 6384-6389.

17. Zhang JD, Xu Z, Cao YB, Chen HS, Yan L, An MM, Gao $P H$, Wang $Y$, Jia $X M$, Jiang $Y Y$. Antifungal activities and action mechanisms of compounds from Tribulus terrestris L. J. Ethnopharmacol., 2006; 103(1): 76-84.

18. Einhellig FA, Leather GR, Hobbs LL. Use of Lemna minor $L$. as a bioassay in allelopathy. J. chem. Ecol., 1985; 11: 65-72.

19. Zhu J, Liu B, Jing W, Yunni G, Zhenbin W. Study on the mechanism of allelopathic influence on cyanobacteria and chlorophytes by submerged macrophyte (Myriophyllum spicatum) and its secretion. Aquat. Toxicol., 2010; 98(2): 196-203

20. Harwig J, Scott P. Brine shrimp (Artemia salina L.) larvae as a screening system for fungal toxins. Appl. Microbiol., 1971; 21: 1011-1016.

21. Rieser MJ, Gu ZM, Fang XP, Zeng L, Wood KV, McLaughlin JL. Five novel mono-tetrahydrofuran ring acetogenins from the seeds of Annona muricata. J. Nat. Prod. 1996; 59: 100-108.

22. Mishra LC, Singh BB, Simon D. Scientific basis for the therapeutic use of Withania somnifera 
(ashwagandha) Altern. Med. Rev. 2000; 5(4): 334346.

23. Ichikawa H, Takada Y, Shishodia S, Jayaprakasam B, Nair MG. Withanolides potentiate apoptosis, inhibit invasion, and abolish osteoclastogenesis through suppression of nuclear factor-KB (NF-KB) activation and NF-KB-regulated gene expression. Mol. Canc. Ther. 2006; 5(6): 1434-1445.

24. Davis L, Kuttan G. Effect of Withania somnifera on CTL activity. J. Exper. Cin. Canc. Res. 2002; 21(1): 115118 